\title{
Mastery of Active and Shared Learning Processes for Techno-Pedagogy (MASLEPT): A Model for Teacher Professional Development on Technology Integration
}

\author{
Michael Nkwenti Ndongfack \\ Higher Teacher Training College, University of Yaounde I, Yaounde, Cameroon \\ Email: mikesman2002@yahoo.com
}

Received 19 November 2014; accepted 10 December 2014; published 13 January 2015

Copyright (C) 2015 by author and Scientific Research Publishing Inc.

This work is licensed under the Creative Commons Attribution International License (CC BY).

http://creativecommons.org/licenses/by/4.0/

\section{(c) (i) Open Access}

\section{Abstract}

As schools increasingly adopt new technologies in enhancing teaching and learning, models of teacher professional development are also evolving. To ensure that teacher development programmes effectively assist them in integrating technology in instructional processes, a study was conducted to determine a more acceptable model of teacher professional development. This study employed a quantitative survey methodology in the collection of data towards the development of a model on technology integration in classrooms and the identification of training needs for teachers. A total of $\mathbf{4 0 0}$ teachers were selected to participate in this study using the stratified random sampling technique from primary schools in 10 Regions of Cameroon to identify their preferences in a professional development model. The data was analysed using percentages, frequency counts, mean and standard deviation. The results indicated that teacher-participants showed a strong preference for an on-going school-based professional development model that supports collaborative learning, problem solving and involves classroom follow-up. A review of the weaknesses in current models as well as literature on best practices in in-service teacher training led to the proposed Mastery of Active and Shared Learning Processes for Techno-pedagogy (MASLEPT) model.

\section{Keywords}

Technological Pedagogical Content Knowledge, Technology Integration Model, Information and Communication Technology Integration 


\section{Introduction}

In 2009, Cameroon published the Growth and Employment Strategy Paper aimed at transforming the country into an emerging nation by 2035. One of the strategies to achieve the vision is the development of the required human capital by the education sector. Qualified human resources in Information and Communication Technology (ICT) play a key role in leapfrogging nations to emerging country status (Partners for 21st Century Skills, 2009). Building a competent ICT workforce to drive the vision will require pupils to start acquiring technological skills while still in primary school. For this to be effective, teachers should be empowered to adequately use technology in instructional processes. Since ICT was introduced in the Cameroon primary school curriculum, very little in-service training has been conducted to empower teachers to adapt technology in teaching and learning (Inspectorate of Pedagogy in Charge of ICT, Annual Reports, 2009, 2010, 2011). An effective professional development model on technology integration in classroom practices is a pre-requisite for them to use the tools.

Professional development should be intentional, on-going, and a systemic process aimed at increasing the knowledge-base of teachers about a topic that will in turn increase their knowledge and the achievement of their pupils (Guskey, 2000). Ingvarson (2005) remarked that “there are no short cuts to educational improvement” (p. 63). Stakeholders often have naive expectations about the ease with which educational change can occur, not understanding that the most significant changes are those that build teachers' capacity and professional culture. Instead they often focus on building structures and reforming school curriculum framework (McDonald, 2009). Petersen, Mcarthy, and Elmore (1996) commented in their research on the capacity of "restructuring” reforms in the United States to benefit classroom practice, "school structures can provide opportunities for the learning of new teaching practices and new strategies for pupils' learning, but structures, by themselves, do not cause learning to occur” (p. 149). Therefore, stakeholders must redirect their focus towards on-going quality teacher professional development programmes.

For teachers to be able to use technological tools in their classrooms, an effective professional development model must be put in place to improve their skills (McDonald, 2009). Several studies have proven that effective teacher professional development leads to the enhancement of teachers' knowledge and skills (Hanley, Maringe, \& Ratcliffe, 2008; Lieberman \& Pointer-Mace, 2008). Yoon, Duncan, Lee, Scarloss and Shapley (2007) affirmed that effective teacher professional development contributes to pupils' improved learning outcomes. The improvement in pupils' academic achievement is the ultimate aim of teacher professional development (Borko, 2004; Guskey \& Sparks, 2002; McRae, 2003; Rock \& Wilson, 2005). Adequate professional development for teachers on the adoption of technology in their classroom will empower them to use the tool to improve pupils' achievement. This paper surveys primary school teachers' views on their preferred professional development model and concludes with recommendations for stakeholders.

\section{Model of Teacher Professional Development in Cameroon Primary Schools}

The teacher professional development model that has been in practice in Cameroon primary schools for the past two decades is the pedagogic day seminar (Inspectorate General of Pedagogy, 2004; Nkwenti Ndongfack, 2010). The pedagogic day seminars are organised at Sub-Divisional levels which are usually held in a nearby school or at the Sub-Divisional Inspectorate for Basic Education with the goal of improving teachers’ professional knowledge, skills and attitudes. These seminars are organised by the Sub-Divisional Inspectors in collaboration with Regional Pedagogic Inspectors (Inspectorate of Pedagogy in Charge of ICT, Annual Reports, 2009). The seminars are held once a term and last for a day, accumulating to three days per school year (about 18 hours of effective instruction).

Guskey (2000), Supovich and Turner (2000) recommended that for a teacher professional development programme to be effective, it should be held for a minimum of 60 to 80 hours annually. This indicates that the duration for which professional development of teachers on the use of ICT conducted in Cameroon is largely insufficient. This view is further confirmed by the Inspectorate of Pedagogy in Charge of ICT, Annual Reports (2009, 2010, 2011) which highlights that in-service primary school teachers regularly complain of the short duration of professional development on the use of ICT for instructional purposes. Pedagogic day seminars offer brief interventions which are ineffective in promoting long term or lasting change in teachers' practice. Fraser (2005) remarked that this model of professional development is characterized by knowledge transmission rather than reflective thinking and exchange of ideas. This view was further confirmed by Tante (2010) who uphold 
that

“... in the Cameroon primary educational system, opportunities for in-service training and teacher development are sparse and intermittent, in most cases just once a year. The training and staff development follow the transmission model and the sessions are hardly evaluated, nor are implementation of training monitored” (p. 27).

Crawford (2000), Guadelli (2002) and Fraser (2005) observed that the pedagogic day seminar also known as the one-shot workshop model for teacher professional development is practised by many countries. Despite the widespread applicability of the model, the researchers argue that it does not promote long term change in teachers' practice and has generally failed to transform what teachers do in the classroom. One of the reasons identified by the researchers is that there is usually no follow-up after the training. Even if participants felt that it was beneficial, the likelihood that they would integrate the skills and knowledge acquired into their practises and maintained them over time is very slim. Guadelli (2002) commented that teachers from the same school attending this model of professional development have very little chance of continuous collaboration and networking after the event because of no follow-up and support. The researchers concur with this view because working as an Inspector of Pedagogy in the Ministry of Basic Education for the past eight years and a teacher educator for 23 years, the limited number of supervisory staff and other resources cause a limited follow-up of teachers after their participation in the pedagogic day seminar. The lack of proper follow-up indicates that teachers will be unable to build on the knowledge and skills discussed at the workshop or get practical support from their colleagues to effectively integrate technological knowledge into their practices. Based on the weaknesses observed in the existing model of teacher professional development on technology integration, this study was conducted with the following research question in mind:

"What professional development model will empower in-service primary school teachers to develop their knowledge of technology, pedagogy and content to effectively adopt ICT across the school curriculum”?

\section{Characteristics of an Effective Professional Development Model}

Rogers (2007) stated that contemporary professional development models have moved from short-term teachertraining events where information was transmitted by an expert to a group of listening participants, to a more constructivist approach. The constructivist model of teacher professional development is perceived as being more effective because it is based upon the recognition that learning takes place over time and that active learning requires learners to connect new ideas to previous knowledge (Upitis, 2005). Guskey (2003) and McDonald (2009) have all provided descriptions of what characterises an efficient professional development model for teachers. They all seem to be unanimous that effective professional development of teachers should have positive effects on pupils' learning outcomes.

Hawley and Valli (1999) analyse studies conducted on professional development to identify factors that foster pupils' learning. Their findings resulted in the identification of nine factors that characterise the design of an effective professional development programme. The researchers recommend that professional development models should:

- be focused on what teachers teach to their pupils and misconceptions pupils may face learning the materials and how they can be addressed;

- be based on analyses of the differences between actual pupils’ performance, goals and standards for pupils' learning;

- involve teachers in the identification of what they need to learn and in the development of the learning experiences in which they will be involved;

- be primarily school-based and built into the day-to-day teaching programme;

- be organised around collaborative problem solving;

- be continuous and on-going, involving follow-up and support for further learning;

- incorporate best practices in implementing lessons learned through professional development;

- provide opportunities to gain understanding of the theory underlying the knowledge and skills being learned; and

- be connected to a comprehensive change process focused on improving pupils’ learning. Similarly, Ingvarson (2005); Lieberman and Pointer Mace (2008) and Plummer (2005) also reviewed litera- 
ture focusing on the principles of effective professional development. The rationale for the review was to identify factors that were most prominent in teacher professional development programmes. The findings revealed most commonly agreed principles of effective professional development amongst educators and practitioners. They suggested that professional development should be a demonstration of how pupils learn; be continuous, include follow-up; be part of a comprehensive approach or strategy to instructional improvement; be a process that provides teachers with learning opportunities which are meaningful, intellectually engaging and professionally empowering.

In the same perspective, the findings of Guskey (2003) synthesize a list of twelve fairly representative samples of effective professional development conducted in the United States. The rationale of the study was to identify the factors that were recurrent in most effective professional development models. According to Guskey (2003), the most frequently-cited characteristics in order of frequency of inclusions were the enhancement of teachers' content and pedagogical knowledge; provision of sufficient time and resources; promotion of collegiality and collaborative exchange; inclusion of specific evaluation procedures; alignment with other reform initiatives; modelling of high quality instruction and be school or site-based.

\section{Theoretical Framework}

From the literature reviewed, it can be discerned that an effective professional development model should be characterised by teachers' pedagogical content knowledge; provision of sufficient time and resources; promotion of collegiality and collaborative exchange; include follow up procedures; models high quality instruction and be school or site-based. In this regards, three key factors comes into play. Firstly, given that teachers' pedagogical content knowledge is paramount in any teaching and learning process, the Technological Pedagogical Content Knowledge (TPACK) framework for understanding the complexity of integrating technology into specific subject matter can provide solid background knowledge for teachers to teach using technology (Mishra \& Koehler, 2006).

Before technology was readily made available to teachers, they considered two basic issues during lesson planning and teaching: which content to teach and how to teach it which may have been made separately or in a concerted manner. Shulman $(1987,1986)$ introduced the concept of pedagogical content knowledge (PCK) as the way pedagogy and content knowledge can be blended to provide an understanding on how particular topics to be taught can be represented and adapted to pupils' characteristics, interests and abilities. Specifically, PCK relates to the transformation of several types of knowledge which includes an understanding of what makes the learning of specific concepts easy or difficult and "embodies the aspects of content most germane to its teachability” (Shulman, 1986: p. 9). This transformation occurs as the teacher critically reflects on and interprets the subject matter; finds multiple ways to represent the information as analogies, metaphors, examples, problems, demonstrations, and/or classroom activities; adapts the material to pupils' developmental levels and abilities, gender, prior knowledge, and misconceptions; and finally tailors the material to those specific individuals or groups of pupils to whom the content will be taught.

Mishra and Koehler (2006) upgraded Shulman's PCK by introducing technology to include teachers' understanding of teaching specific content with appropriate pedagogical methods and technologies. Just as Shulman argued that content and pedagogy should not be viewed as separate domains, Mishra and Koehler (2006) argued the same for the inclusion of the technology domain. Mishra and Koehler (2006) argue that,

Though Shulman's approach still holds true, what has changed since the 1980s is that technologies have come to the forefront of educational discourse primarily because of the availability of a range of new, primarily digital, technologies and requirements for learning how to apply them to teaching (p. 1023).

Acknowledging the significant role of ICT in the teaching and learning process, Mishra and Koehler (2006) proposed the integration of technology into Shulman's (1987) PCK model and named the resulting combination, Technological Pedagogical Content Knowledge (TPACK). TPACK is used in this study as one of the frameworks to guide the design of the content of the teacher professional development programme.

Secondly, Lesson Study is a well-documented school-based teacher professional development model which originated from Japan in the $18^{\text {th }}$ century (Baba \& Kojima, 2004; Fernandez \& Yoshida, 2004; Hashimoto et al., 2003). The underlying principle of the model requires groups of teachers to meet regularly over an extended period of time, to work on the design, implementation, feedback, and improvement of one or several "research 
lessons” (Baba \& Kojima, 2004; Fernandez \& Yoshida, 2004; Stigler \& Hiebert, 1999). Research lessons are authentic classroom lessons taught by the teacher to their own class. They are:

- focused on a specific, pre-determined teacher-generated problem, goal, or vision of pedagogical practice;

- carefully planned, usually in collaboration with one or more colleagues;

- observed by other teachers;

- recorded for analysis and reflection; and

- discussed by group members, other colleagues, administrators or an invited commentator (Lewis \& Tsuchida, 1998).

In designing their lessons that integrate technology, teachers identify areas that pupils are likely to have difficulties in understanding. To resolve the difficulties, teachers may proceed to identifying how technology can be used to further illustrate the difficult or abstract concepts. When the teachers complete the study, they document their work in a report that describes the lesson they designed, explain how the lesson worked and what they have learnt about teaching and learning using ICT from the lesson study experience (Baba \& Kojima, 2004; Fernandez \& Yoshida, 2004). This model enables teachers to be collaboratively engaged in action research in order to improve the quality of instruction using technology as clearly outlined by the literature on best practices in effective teacher professional development programmes (Lewis, Perry, Hurd, \& O’Connell, 2006).

Thirdly, social constructivism is one of the most appropriate theoretical frameworks that support the teacher professional development model. Dewey (1916) suggested that experience is the cornerstone from which new knowledge is created, promoting authentic learning and meaningful experiences that foster new knowledge growth. This perspective gave rise to a theoretical perspective known as constructivism. Widely accepted within the educational community, constructivism describes learning as a process whereby learners actively construct or build new ideas, concepts, or knowledge objects based upon existing understandings. Vygotsky (1962), a cultural psychologist theorized that language and conceptual development are linked to social phenomena and cultural contexts. Vygotsky (1978) extended the perspectives of constructivism by theorizing that learning occurs through sociocultural mediation, meaning that individuals construct new knowledge through their active participation within a social context and via interactions with its signs and tools. Social constructivism recognises that teachers grow from a relationship with a trusted confidant with whom they can establish and continue dialogue about ways of developing their understandings. It guided the design of interactive activities that teachers' undertook throughout a professional development programme.

\section{Methodology}

The study employed quantitative research methodology in the development of the model. It targeted 53,452 public primary school teachers teaching in 14,712 primary schools nation-wide. The application of Research Advisors (2006) spreadsheets in calculating the sample size for this study yielded 378 schools and 382 teachers with approximately 218 females and 164 males at a confidence level of $95 \%$ and a margin of error (degree of accuracy) of 5\%. According to the Ministry of Basic Education Statistical Year Book (2011), 57\% of the primary school teachers are females while $43 \%$ are males; $50 \%$ of the teachers teach in urban schools, $30 \%$ teach in semi urban schools while $20 \%$ teach in rural schools. These variables were taken into consideration when selecting the sample for this study. For easy distribution of the sample size across the ten Regions of Cameroon, taking into consideration gender and location of the teachers, the researcher increased the number to 400 (230 females and 170 males) teachers which is greater than the minimum sample size suggested by Research Advisor (2006). The sample seize for schools remained the same. From the Ministry of Basic Education Statistical Year Book (2011), 38\% of the primary schools are in urban settlements; $22 \%$ in semi-urban settlements while $40 \%$ are in rural settlements.

After determining the sample, proportionate sampling technique was applied in the selection of schools from each region taking into consideration the type of settlement. Proportionate sampling technique is used when the researcher knows the distribution of target schools or population across a set of groups and when there is a desire to ensure that minorities are properly represented in the study (Moore \& McCabe, 2005). This guideline enabled the researchers to identify the groups to be used for the sub-segments and the proportion of the population in each group. To get the sample for each group, the percentages were multiplied by the total sample size as seen in Table 1. The table indicates the distribution of participating schools per region in terms of school location. The Centre Region had the highest number of schools because it is highly populated. It is worth noting that 
Table 1. Number of participating schools from each region in terms of school location.

\begin{tabular}{ccccc}
\hline Region & $\begin{array}{c}\text { Number of primary } \\
\text { schools }\end{array}$ & Rural & School location & Urban \\
\cline { 3 - 5 } Adamawa & 22 & 9 & 5 & 8 \\
Centre & 65 & 26 & 14 & 25 \\
East & 23 & 9 & 5 & 9 \\
Far North & 50 & 20 & 11 & 19 \\
Littoral & 43 & 17 & 9 & 17 \\
North & 29 & 12 & 6 & 18 \\
North West & 49 & 19 & 10 & 18 \\
West & 47 & 19 & 7 & 11 \\
South & 29 & 12 & 5 & 8 \\
South West & 21 & 8 & 83 & 144 \\
Total & 378 & 151 & & 11 \\
\hline
\end{tabular}

the schools were distributed in terms of the number of schools in each region.

Table 2 indicates the demographic information of teachers in terms of gender, age, and teaching experience. The bulk of the participants were females because $52.5 \%$ of teachers teaching in Cameroon primary schools are females.

\subsection{Data Collection}

Quantitative data were collected through a nation-wide survey involving 400 in-service primary school teachers. To respond to the research question, survey questionnaires containing Likert Scale items were administered to 400 teacher-participants selected using the stratified random sampling technique from the 10 Regions of Cameroon. The test items were designed to investigate their preferred professional development model and its characteristics.

\subsection{Results}

Research Question: What professional development model will empower in-service primary school teachers to develop their knowledge of technology, pedagogy and content to effectively adopt ICT across the school curriculum?

Table 3 represents the responses of teacher-participants who were surveyed on eleven statements related to their preferred professional development model and its characteristics on a 5-point Likert Scale items. The first three statements on the table were designed to investigate teacher-participants' preferred professional development model while the remaining eight were formulated to find out what should characterise the model. Regarding their preference for a standardised professional development model; 183 (47.4\%) teacher-participants were not in favour of the model, 73 (18.3\%) were in favour of it while about 130 (34\%) remained neutral. Concerning the self-learning professional development model, 229 (57.6\%) teacher-participants were not in favour of such a model. In reference to a school-based professional development model, 368 (92\%) supported such a model. From their responses on standardised, self-learning and school-based professional development model, it was concluded that 368 (92\%) teacher-participants were in favour of a school-based professional development model as compared to 73 (18.3\%) for standardised and 77 (19.4\%) for self-learning models respectively.

With their interests settled on a school-based professional development model, 322 (90\%) teacher-participants preferred an on-going professional development model whilst 376 (94.3\%) teacher-participants preferred the professional development model to address the challenges faced in their classrooms. With regards to the collaborative nature of the model, 381 (95.2\%) teacher-participants were of the opinion that the professional development model support collaborative learning with colleagues. Additionally, 368 (92.1\%) of them would feel 
Table 2. Demographic information of teacher-participants.

\begin{tabular}{cccccc}
\hline Description & \multicolumn{3}{c}{ Male } & \multicolumn{2}{c}{ Female } \\
\hline \multirow{2}{*}{ Participants } & Frequency & Percentage & Frequency & Percentage \\
Age & & 170 & 42.5 & 230 & 57.5 \\
& $<32$ years & 57 & 14.25 & 72 & 18 \\
& $\geq 32$ years & 113 & 28.25 & 158 & 39.5 \\
Teaching experience & $\leq 5$ years & 44 & 11 & 67 & 16.75 \\
& $6-10$ years & 49 & 11.25 & 63 & 13.25 \\
& $11-15$ years & 44 & 33 & 50 & 15 \\
\hline
\end{tabular}

Table 3. Teacher-participants’ preferences of a professional development model.

\begin{tabular}{|c|c|c|c|c|c|c|c|c|}
\hline Statement & SD & $\mathrm{D}$ & $\mathrm{N}$ & A & SA & NR & Mean & STD \\
\hline $\begin{array}{l}\text { I prefer the standardised professional } \\
\text { development model currently in practice }\end{array}$ & $\begin{array}{c}37 \\
(9.3 \%)\end{array}$ & $\begin{array}{c}146 \\
(36.5 \%)\end{array}$ & $\begin{array}{c}130 \\
(32.5 \%)\end{array}$ & $\begin{array}{c}45 \\
(11.3 \%)\end{array}$ & $\begin{array}{c}28 \\
(7.0 \%)\end{array}$ & 386 & 2.69 & 1.03 \\
\hline $\begin{array}{l}\text { I prefer a self-learning professional } \\
\text { development model }\end{array}$ & $\begin{array}{c}81 \\
(20.6 \%)\end{array}$ & $\begin{array}{c}148 \\
(37 \%)\end{array}$ & $\begin{array}{c}83 \\
(20.8 \%)\end{array}$ & $\begin{array}{c}60 \\
(15 \%)\end{array}$ & $\begin{array}{c}17 \\
(4.4 \%)\end{array}$ & 398 & 4.20 & 0.72 \\
\hline $\begin{array}{l}\text { I prefer a school-based professional } \\
\text { development model }\end{array}$ & $\begin{array}{c}03 \\
(0.8 \%)\end{array}$ & $\begin{array}{c}13 \\
(3.3 \%)\end{array}$ & $\begin{array}{c}14 \\
(3.5 \%)\end{array}$ & $\begin{array}{l}236 \\
(59 \%)\end{array}$ & $\begin{array}{c}132 \\
(33 \%)\end{array}$ & 389 & 2.44 & 1.11 \\
\hline $\begin{array}{l}\text { I prefer the professional development } \\
\text { model to be an on-going one }\end{array}$ & $\begin{array}{c}08 \\
(2.0 \%)\end{array}$ & $\begin{array}{c}18 \\
(4.5 \%)\end{array}$ & $\begin{array}{c}51 \\
(12.8 \%)\end{array}$ & $\begin{array}{c}227 \\
(56.6 \%)\end{array}$ & $\begin{array}{c}95 \\
(23.8 \%)\end{array}$ & 399 & 3.95 & 0.85 \\
\hline $\begin{array}{l}\text { I prefer the professional development } \\
\text { model to address the problems I face in my } \\
\text { classroom }\end{array}$ & $\begin{array}{c}02 \\
(0.5 \%)\end{array}$ & $\begin{array}{c}03 \\
(0.8 \%)\end{array}$ & $\begin{array}{c}18 \\
(4.5 \%)\end{array}$ & $\begin{array}{c}209 \\
(52.4 \%)\end{array}$ & $\begin{array}{c}167 \\
(41.9 \%)\end{array}$ & 399 & 4.34 & 0.64 \\
\hline $\begin{array}{l}\text { I prefer the professional development } \\
\text { model to support collaborative learning } \\
\text { with my colleagues }\end{array}$ & $\begin{array}{c}00 \\
(00 \%)\end{array}$ & $\begin{array}{c}03 \\
(0.8 \%)\end{array}$ & $\begin{array}{c}15 \\
(3.8 \%)\end{array}$ & $\begin{array}{c}225 \\
(56.1 \%)\end{array}$ & $\begin{array}{c}156 \\
(39.1 \%)\end{array}$ & 399 & 4.33 & 0.58 \\
\hline $\begin{array}{l}\text { I will feel comfortable if the professional } \\
\text { development model facilitates lesson } \\
\text { planning with my colleagues }\end{array}$ & $\begin{array}{c}06 \\
(1.5 \%)\end{array}$ & $\begin{array}{c}08 \\
(2.0 \%)\end{array}$ & $\begin{array}{c}17 \\
(4.3 \%)\end{array}$ & $\begin{array}{c}210 \\
(52.5 \%)\end{array}$ & $\begin{array}{c}158 \\
(39.6 \%)\end{array}$ & 399 & 4.26 & 0.76 \\
\hline $\begin{array}{l}\text { I will feel comfortable if the professional } \\
\text { development model enables my colleague(s) } \\
\text { observe me teach and make criticisms }\end{array}$ & $\begin{array}{c}01 \\
(0.3 \%)\end{array}$ & $\begin{array}{c}06 \\
(1.5 \%)\end{array}$ & $\begin{array}{c}18 \\
(4.5 \%)\end{array}$ & $\begin{array}{c}205 \\
(51.4 \%)\end{array}$ & $\begin{array}{c}169 \\
(42.4 \%)\end{array}$ & 399 & 4.34 & 0.66 \\
\hline $\begin{array}{l}\text { I will like to have a follow-up after } \\
\text { participating in a professional } \\
\text { development programme }\end{array}$ & $\begin{array}{c}03 \\
(0.8 \%)\end{array}$ & $\begin{array}{c}04 \\
(1.0 \%)\end{array}$ & $\begin{array}{c}21 \\
(5.3 \%)\end{array}$ & $\begin{array}{c}207 \\
(51.9 \%)\end{array}$ & $\begin{array}{c}164 \\
(41.1 \%)\end{array}$ & 399 & 4.31 & 0.68 \\
\hline $\begin{array}{l}\text { I will like the follow-up to take place in } \\
\text { my classroom }\end{array}$ & $\begin{array}{c}10 \\
(2.5 \%)\end{array}$ & $\begin{array}{c}15 \\
(3.8 \%)\end{array}$ & $\begin{array}{c}29 \\
(7.3 \%)\end{array}$ & $\begin{array}{c}241 \\
(60.4 \%)\end{array}$ & $\begin{array}{c}104 \\
(26.1 \%)\end{array}$ & 399 & 4.03 & 0.84 \\
\hline $\begin{array}{l}\text { I will like the follow-up to take place } \\
\text { through online discussions }\end{array}$ & $\begin{array}{c}73 \\
(18.4 \%)\end{array}$ & $\begin{array}{c}118 \\
(29.8 \%)\end{array}$ & $\begin{array}{c}126 \\
(31.5 \%)\end{array}$ & $\begin{array}{c}02 \\
(15.9 \%)\end{array}$ & $\begin{array}{c}16 \\
(4.0 \%)\end{array}$ & 396 & 2.57 & 1.08 \\
\hline Total & & & & & & & 3.76 & 0.81 \\
\hline
\end{tabular}

Note: Strongly Disagree ( $S D=1)$, Disagree $(\mathrm{D}=2)$, Neutral $(\mathrm{N}=3)$, Agree $(\mathrm{A}=4)$, Strongly Agree $(\mathrm{SA}=5)$, Number of Respondents $(\mathrm{N})$, Standard Deviation (STD).

comfortable if the professional development model facilitates lesson planning with their colleagues. Regarding their colleagues observing them teach and providing critical feedback, 374 (93.8\%) teacher-participants indicated that they will feel comfortable if the professional development model enabled their colleagues to observe them teach and make criticisms. Regarding follow-up, 371 (93\%) teacher-participants were in favour of a follow-up after participating in the professional development programme. About 345 (86.5\%) indicated their desire for a classroom follow-up. Although a majority indicated their interest for a follow-up after their professional 
development, 191 (48.2\%) teacher-participants disagreed on using online follow-up while 18 (19.9\%) showed interest and $126(40 \%)$ remained neutral to the view. The overall mean and standard deviation for the construct were Mean $=3.76$ and STD $=0.81$ respectively. The small standard deviation $(\mathrm{STD}<1.00)$ indicates that they were clustered closely around the mean.

From the results, it can be established that the teacher-participants preferred a school-based professional development model that:

- is on-going;

- addresses the problems faced by teachers in classrooms;

- supports collaborative learning amongst colleagues;

- encourages teachers to plan lessons with their colleagues;

- encourages teachers to observe one another teach and provide feedback;

- encourages follow-up after participation in a professional development programme; and

- encourages follow-up to take place in classrooms.

\section{Discussion of the Findings}

\subsection{School-Based Professional Development Model}

Based on the initial findings and combining aspects of the literature review, a model was developed to guide the development and implementation of professional teacher development in Cameroon (see Figure 1 below).

The MASLEPT model motivates teachers to participate, contribute, guide each other's learning, and give meaning to their common course of developing technology integration skills. It establishes a common ground which gives teachers the motivation to meet, discuss and share their views on how to improve their pupils' learning outcomes through the use of technology in their classrooms. In so doing, the model contributes in defining the identity of the teachers because coming together for a common purpose implies a commitment to

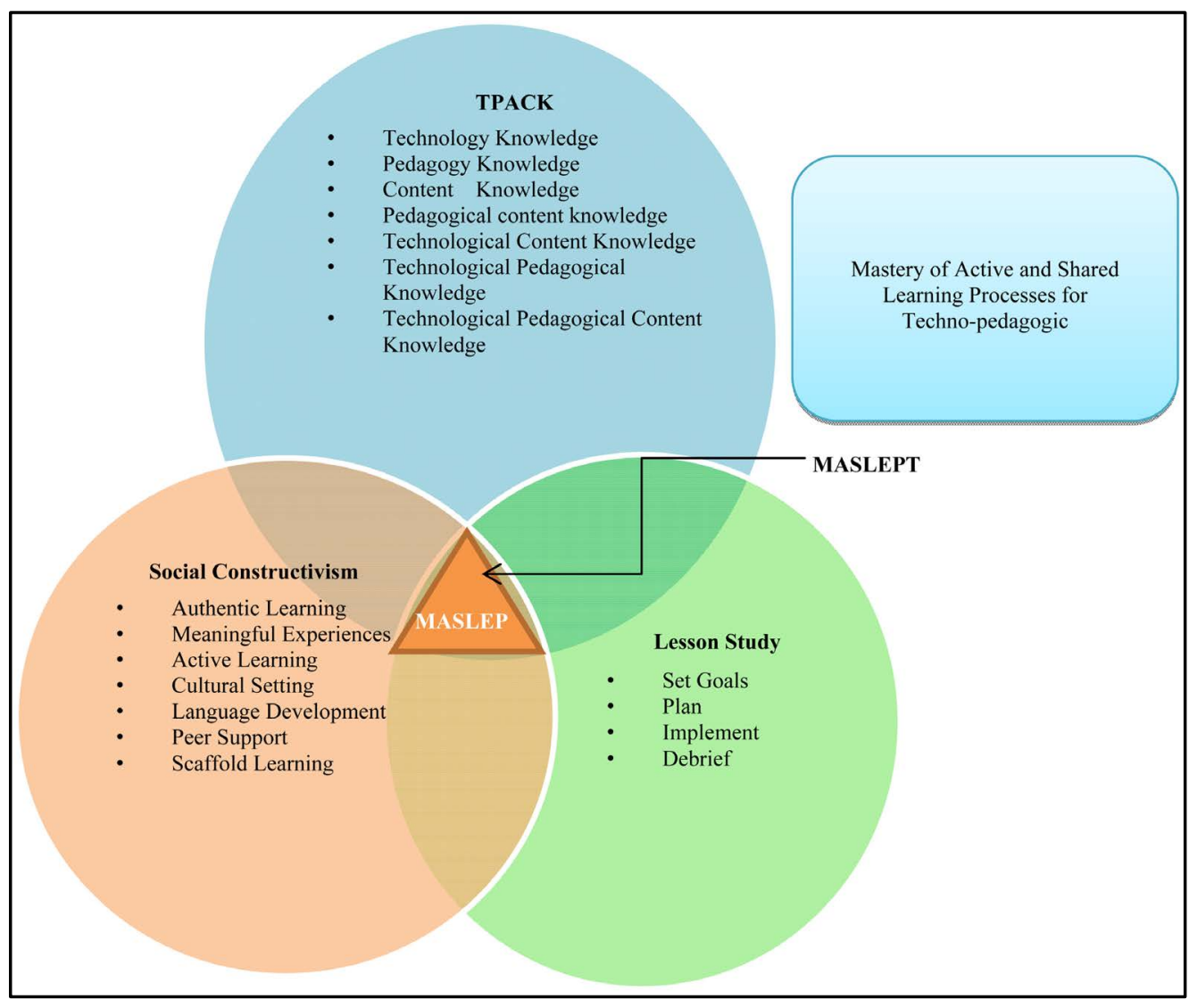

Figure 1. MASLEPT model for Cameroon 2035 Learning. 
shared competencies that distinguishes them from others. As they engage in the model, they will undertake common activities, share ideas, reflect on their experiences and support each other. Their participation in these activities and the relationships that they create enable them to learn from each other and grow professionally.

The MASLEPT model draws inspiration from a community of practice. Wenger, McDermott and Snyder (2002) propose that the terms "community of practice" refer to "a very specific type of social structure with a very specific purpose" (p. 41). The specific purpose within the framework of this study is the development of technology integration skills by in-service primary school teachers to enable them prepares pupils who can transform Cameroon to an emerging nation by 2035. Members of a community of practice are "informally bound by what they do together" (Wenger, 1998: p. 2). They interact and learn together by engaging in joint activities around their shared domain of interest (Gray, 2004). The existence of these common situations, problems and perspectives is what brings teachers together to share knowledge and to learn from each other as they develop technology integration skills.

\subsection{Implementation of the MASLEPT Model}

To successfully implement MASLEPT, the model has further been simplified as seen in Figure 2. The first part

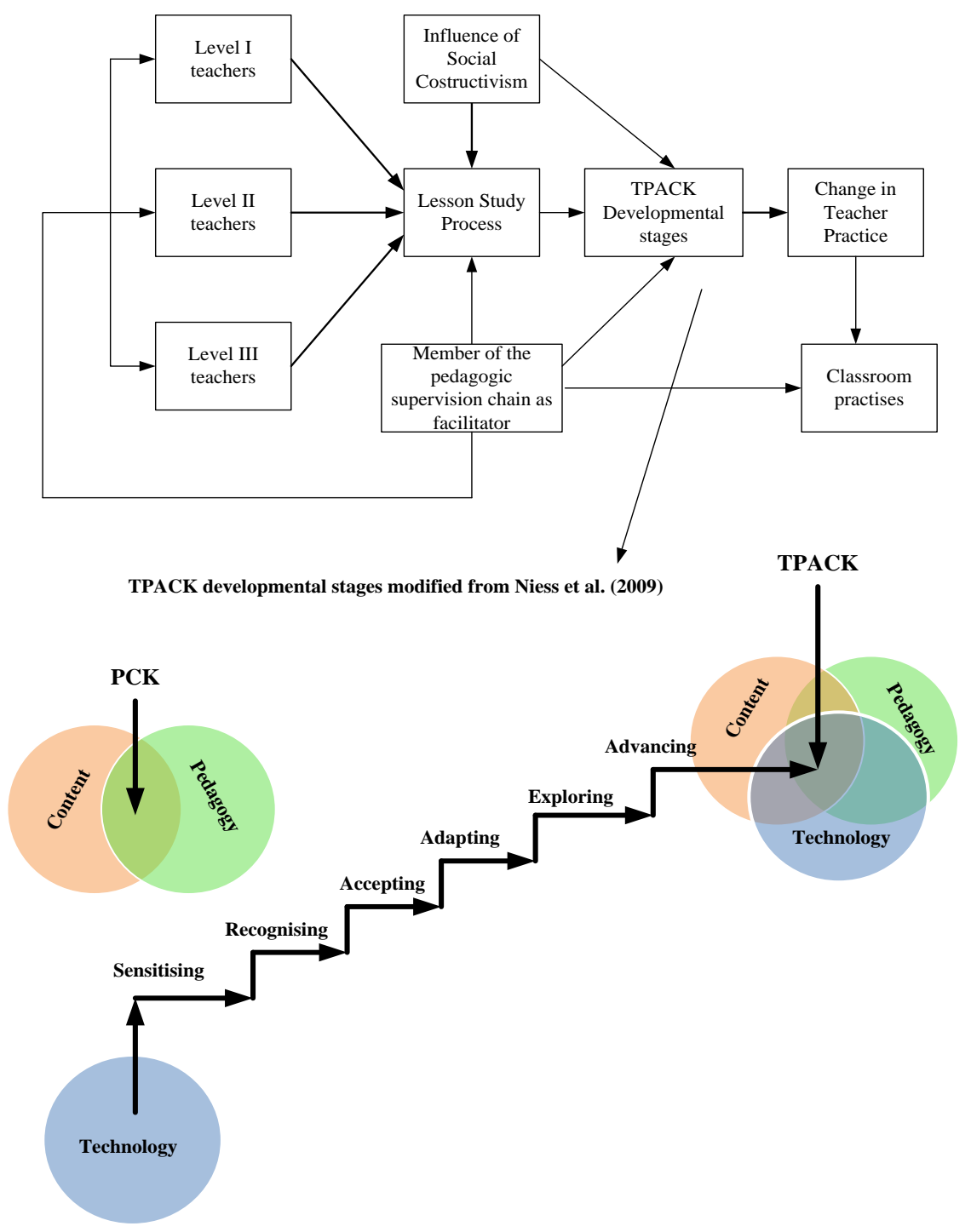

Figure 2. School-based teacher professional development model for technology integration (MASLEPT). 
of the diagram depicts the processes teachers are expected to go through to build their skills to mainstream technology in the school curriculum while the second part illustrate the different stages they are expected to work through to develop their capabilities. The MASLEPT model indicates that during a professional development programme, a member of the pedagogic supervision chain such as a head teacher, pedagogic animator, pedagogic adviser or regional pedagogic inspector playing the role of a facilitator, clusters teachers according to levels (Level I, II, III). The facilitator proceeds by guiding the teachers in setting technology-driven lesson goals, planning the lessons, implementing the lessons and reflecting on its outcomes. The activities that take place during the process are highly influenced by social constructivist theorists. The teachers continue the practice together by working through the TPACK developmental stages as seen in the second part of the diagram to master the art of mainstreaming technology with content and pedagogy. As the process goes on, teachers' practises change. This change influence their teaching and learning in the classroom. A member of the pedagogic chain continues with the provision of classroom support to ensure that the change in teachers' routine practises is sustainable. The role of a member of the pedagogic chain is very important in the entire process.

The developmental stages as seen in the MASLEPT model indicate how Cameroon in-service primary school teachers can be guided to develop their knowledge of technology, pedagogy and content as an amalgamation. The sole challenge lies in the fact that the use of technology in the Cameroon primary school curriculum is still in its incubation stage (Ndongfack, 2010). Niess, Ronau, Shafer, Driskell, Harper, and Johnston (2009) model originally kick starts teachers at the recognising stage. For this study, an extra stage called "sensitising" was added because the context in which the original model was developed is not the same as Cameroon. Therefore the original model could not be directly applicable in the Cameroon primary school settings. The researcher modified it to include a sensitising stage at the beginning of the model. The sensitising stage will enable in-service teachers who have never had the opportunity to learn how technology can enhance teaching and learning practices to become acquainted. Most primary schools in the country are located in rural areas where teachers are rarely exposed to innovative pedagogic practices. For them to modernize their traditional classroom practices, they obviously need an understanding of the impact of the tool in the teaching-learning process. This will not only help in sensitising them on the importance of the tool but will also serve as a way of combating resistance to change.

One of the strong points of the school-base teacher professional model is that it is on-going. An on-going professional development model empowers teachers to constantly keep pace with innovative pedagogic practices in the field of educational technology (Hawley \& Valli, 1999). Besides, teachers will be able to meet up with the minimum recommended duration of an effective professional development of 60 to 80 hours annually (Guskey, 2000; Supovich \& Turner, 2000).

Given that the training took place within the school environment, teachers in the nation-wide survey were largely in favour of the fact that the professional development programme should address specific problems they face in their classrooms. Professional development programmes that are based on problem-solving are said to be time bound. Time-bound in this context refers to the provision of a just-in-time solution. Such programmes have proven to be very effective in providing a sustainable solution to problems teachers face in their routine practices. When teachers' specific problems are addressed in a professional development programme, their classroom practises change. If the application of knowledge learned from a professional development programme leads to a change in pupils' learning outcomes, the teachers' attitudes and belief changes (Guskey, 2002).

The collaborative nature of the school-based professional development model as solicited by the teacher-participants is also one aspect that fosters teacher professional growth. Social constructivist theory argues that learning occurs through socio-cultural mediation (Vygotsky, 1978). This means that teachers will construct new knowledge through their active participation in the professional development programme and via interactions with various learning technologies. As teachers work collaboratively during the professional development programme, the more knowledgeable ones with technological skills support the less experienced colleagues. The MASLEPT model reinforces this practice because it enables teachers in a professional development programme to come together to set technological lesson goals, plan the lessons, implement them and reflect on its outcomes.

Lewis and Tsuchida (1998) uphold that when teachers work through the lesson study cycle as seen in the MASLEPT model, they produce authentic classroom lessons that are focused on a specific pre-determined problem, goal, or expected learning outcome. Since the teachers work collaboratively, the lessons are carefully planed, observed by other teachers, analysed and reflected upon by group members, administrators or an invited commentator. In such processes, social constructivism is very much in action because social negotiations, dis- 
cussions, reflections and explanations lead to a positive learning outcome (Rock \& Wilson, 2005). Collaborative lesson planning improves the effectiveness of the learning experiences teachers provide to their pupils. To this end, teacher learning is examined in terms of pupils' learning outcomes. When teachers learn collaboratively, it becomes eminent that they will engage pupils in collaborative learning activities (Fraser, 2005).

Given that the professional development model is school-based, teacher-participants in the nation-wide survey opted for a classroom follow-up. Classroom follow-up is one of the characteristics of an effective professional development programme identified by many practitioners (Ingvarson, 2005; Lieberman \& Pointer Mace, 2008; Plummer, 2005). Classroom follow-up contributes significantly in enhancing teacher professional growth because they receive instant feedback on their challenges. The one-shot model currently in practice offers very little classroom follow-up to teachers. The new Organisational Chart of the Ministry of Basic Education (2012) clearly traces the pedagogic supervision system. The MASLEPT teacher professional development model suggested in this study requires a member of the pedagogic supervision system to play an active role. As a facilitator in a professional development programme, he/she continues with a classroom follow-up to support teachers in the implementation of the new knowledge. Many studies have shown that professional development programmes fail to yield the expected results because there is usually no follow-up after teachers attend such trainings (Ingvarson, 2005; Lieberman \& Pointer Mace, 2008; Plummer, 2005; Tante, 2010). When there is a classroom follow-up the difficulties teachers face in implementing a lesson can be addressed on the spot. It is worth noting that professional development on technology integration can be very demanding and frustrating at times. Building teachers' confidence as they work up the TPACK developmental stages to become advanced users of technology in instructional processes will be guaranteed through regular classroom follow-up and support as per the MASLEPT model.

\section{Implications for Policy Makers}

The professional development model currently practised in the Ministry of Basic Education assembles teachers of each Sub-Division in a single location for a day (8 hours) and once a term to transmit pedagogic information to them. Since the school year has 3 terms, it means teachers have a total of 36 hours of training annually. Several researchers have challenged this approach as being brief, fragmented, incoherent, decontextualised and isolated from real classroom situations (Crawford, 2000; Guadelli, 2002; Fraser, 2005). Guskey (2000), Supovich and Turner (2000) suggest that for a teacher professional development programme to be effective, it should be held for a minimum of 60 to 80 hours annually. Policymakers should review policies relating to in-service teacher training to ensure that it meets the standards suggested by research. Teacher-participants in the nationwide survey have already shown preference for an on-going school-based professional development model characterised by collaborative learning, classroom follow-up and problem-solving. Policymakers should capitalise on these findings and implement this model in schools nation-wide. This will increase the brief duration of in-service training, improve teachers' quality and transform the school to a true learning organisation for both teachers and pupils.

Policymakers should also explore opportunities through which teachers can be subsidised to own personal computers. Ownership of personal computers has been widely reported by researchers as facilitating learning by teachers themselves, between them and their colleagues or mentors anytime and anywhere (Webb, 2007).

Teachers are in an early stage of technology adoption and thus are likely to face challenges as they try to integrate technology in their lessons. Some of the difficulties may include wrong manipulation of both hardware and software applications. They can become very frustrated if they cannot overcome the challenges. This researcher suggests that the equipment of schools should be accompanied by the intensive training of at least a schoolbased teacher on computer maintenance. The maintenance teacher will subsequently provide support to colleagues when they encounter any difficulties in the use of technology in their classrooms.

\subsection{Implication for Members of the Pedagogic Supervision Chain}

Professional development content that is clearly structured, easy, appropriately sequenced and includes activities to assist teachers in the construction of their own knowledge from previous experiences produces effective teachers. The activities should be related to authentic classroom situations in order to increase teachers' interest in the programme and make learning fun (Koehler \& Mishra, 2006; Webb, 2007). These experiences should be provided in an environment that is comfortable for teachers to explore, experiment and practice with the tools 
and content. Furthermore, activities that are designed to be completed collaboratively produce quality results and build professional relationships whereby expert teachers support the less knowledgeable ones. Collaborative practices that yield better results are those that enable expert teachers or facilitators from within the group to carry out demonstration exercises that are beneficial to teachers with less experience in technology integration into lessons (Fernandez \& Yoshida, 2004). In short, the design of a professional development programme for teachers is very crucial for a successful rollout of the programme.

To ensure that the professional development model is sustainable, practitioners should incorporate into the design a facilitator who is capable of providing clear, effective, and timely feedback to teachers. The facilitator should also be able to model best practices and ensure teachers are engaged throughout the professional development programme. Modelling best practices to teachers is very important because most teachers tend to replicate the activities and practices they learn during professional development programmes into their own teaching practices (Fraser, 2005). Depending on the availability of a facilitator to implement the programme, practitioners may have to design and develop a facilitator's guide. This guide would be created to assist the facilitator with the implementation of the intended programme. Additional training sessions with the facilitator might be necessary depending on the facilitator's technological skills. The designer should consider the facilitator's availability at the beginning of the professional development process, so they can plan accordingly and work within the timeline for implementation.

As teachers begin putting the knowledge and skills gained into practice, they would need access to required resources. Therefore, incorporating an awareness of where and how to access required resources is an important factor to be included in a professional development programme. The implication of this finding aligns with previous research on incorporating appropriate access to resources to increase the sustainability and successful transfer of knowledge and skills developed in a professional development programme to classroom practices (Crawford, 2000; Guadelli, 2002; Fraser, 2005).

\subsection{Conclusion}

The purpose of this study was to develop a more acceptable professional development model for technology integration among primary school teachers to achieve Cameroon's 2035 Vision. The findings from this study indicated that teacher-participants preferred an on-going, school-based professional development model characterised by collaborative learning, problem-solving and classroom follow-up was their prefer in-service training model. School-based professional development models are increasingly being practised in most educational systems around the world to yield high learning outcomes. Though it may seem tedious implementing the model, the reward is ultimately great. No teacher will feel comfortable if challenged by pupils who are increasingly becoming technology savvy because they come from homes that are highly equipped with a variety of technologies. This challenge can be overcome by effectively taking part in the proposed model of teacher professional development. Besides, it is teachers' responsibility to ensure that pupils perform outstandingly in school and become successful citizens in the society and contribute to nation building. This can be achieved if teachers are empowered to help pupils reach their full potential. It is therefore recommended that schools should implement the school-based professional development model. Constant monitoring and evaluating the impact of the model will facilitate the resolution of minor problems while ensuring that the country is on the right track towards the achievement of the 2035 Vision.

\section{Acknowledgements}

A big thank you to Professor Abtar Kaur of Hamdan Bin Mohammed Smart University, Dubai for her excellent mentorship.

\section{References}

Baba, T., \& Kojima, M. (2004). Lesson Study. The History of Japan's Education Development: What Implications Can Be Drawn for Developing Countries? Tokyo: Institute for International Development, JICA.

Borko, H. (2004). Professional Development and Teacher Learning: Mapping the Terrain. Educational Researcher, 33, 3-15. http://dx.doi.org/10.3102/0013189X033008003

Crawford, C. M. (2000). Impacting Learning Environments for Pre-Kindergarten through Graduate School: Technologically Appropriate Professional Development and Classroom Integration Opportunities for Educators. In Proceedings of SITE 
2001: Society for Information Technology and Teacher Education International Conference, Orlando, Florida, ERIC Digest, 124, ERIC Document Reproduction Service No. ED 427820.

Dewey, J. (1916). Democracy and Education. An Introduction to the Philosophy of Education. New York, NY: Free Press.

Fernandez, C., \& Yoshida M. (2004). Lesson Study: A Japanese Approach to Improving Mathematics Teaching and Learning. Mahwah, NJ: Lawrence Erlbaum.

Fraser, C. A. (2005). Towards a Unified Model of Professional Development? Aberdeen: University of Aberdeen. http://www.abdn.ac.uk/cass/pgradconf/papers/ChristineA.Fraser.pdf

Gray, B. (2004). Informal Learning in an Online Community of Practice. Journal of Distance Education, 19, 20-35.

Guadelli, W. (2002). Professional Development, Global Pedagogy, and Potential: Examining an Alternative Approach to the Episodic Workshop. Annual Meeting of the National Council for Social Studies, Washington DC, ERIC Digest, 124, ERIC Document Reproduction Service No. ED 463888.

Guskey, T. R. (2000). Evaluating Professional Development. Thousand Oaks, CA: Corwin Press.

Guskey, T. R. (2003). Professional Development That Works: What Makes Professional Development Effective? Phi Delta Kappan, 84, 748-750.

Guskey, T. R., \& Sparks, D. (1996). Exploring the Relationship between Staff Development and Improvements in Student Learning. Journal of Staff Development, 17, 34-38.

Hanley, P., Maringe, F., \& Ratcliffe, M. (2008). Evaluation of Professional Development: Deploying a Process-Focused Model. International Journal of Science Education, 30, 711-725. http://dx.doi.org/10.1080/09500690701854899

Hashimoto, Y., Tsubota, K., \& Ikeda, T. (2003). Ima Naze Jugyo Kenkyu Ka: Sansujugyo no Saikochiku. Tokyo: Toyokan-Shuppan.

Hawley, W., \& Valli, L. (1999). The Essentials of Effective Professional Development: A New Consensus. In L. Darling-Hammond, \& G. Sykes (Eds.), Teaching as the Learning Profession: Handbook of Policy and Practice (pp. 127-150). San Francisco, CA: Jossey-Bass.

Ingvarson, L. (2005). Getting Professional Development Right. http://www.acer.edu.au/documents/RC2005_Ingvarson.pdf

Inspectorate General of Pedagogy (2004). Annual Report on the General Teaching and Learning across the Primary School Curriculum.

Inspectorate of Pedagogy in Charge of ICT (2009). Annual Report on the Teaching and Learning of ICT across the School Curriculum.

Inspectorate of Pedagogy in Charge of ICT (2010). Annual Report on the Teaching and Learning of ICT across the School Curriculum.

Inspectorate of Pedagogy in Charge of ICT (2011). Annual Report on the Teaching and Learning of ICT across the School Curriculum.

Lewis, C., \& Tsuchida, I. (1998). A Lesson Is like a Swiftly Flowing River. American Educator, 12-17, 50-52.

Lewis, C., Perry, R., Hurd, J., \& O’Connell, P. (2006). Lesson Study Comes of Age in North America. Phi Delta Kappan, 88, 273-281. http://dx.doi.org/10.1177/003172170608800406

Lieberman, A., \& Pointer Mace, D. H. (2008). Teacher Learning: The Key to Educational Reform. Journal of Teacher Education, 59, 226-234. http://dx.doi.org/10.1177/0022487108317020

McDonald, S. E. (2009). A Model of Teacher Professional Development Based on the Principles of Lesson Study. Ph.D. Thesis, Brisbane: Queensland University of Technology.

McRae, D. (2003). Student Learning: The Starting Point for Planning Teacher Learning. Proceedings of the Curriculum Corporation Conference, Perth, Australia.

Mishra, P., \& Koehler, M. J. (2006). Technological Pedagogical Content Knowledge: A New Framework for Teacher Knowledge. Teachers College Record, 108, 1017-1054. http://dx.doi.org/10.1111/j.1467-9620.2006.00684.x

Moore, D. S., \& McCabe, G. P. (2005). Introduction to the Practice of Statistics (5th ed.). New York, NY: W.H. Freeman \& Company.

Niess, M. L., Ronau, R. N., Shafer, K. G., Driskell, S. O., Harper, S. R., \& Johnston, C. (2009). Mathematics Teacher TPACK Standards and Development Model. Contemporary Issues in Technology and Teacher Education, 9, 4-24.

Nkwenti Ndongfack, M. (2010). ICT Integration in Cameroon Primary Schools: A Case Study of Government Primary Practicing School Angele, South Region. Master's Dissertation, Kuala Lumpur: Open University Malaysia.

Partnership for the $21^{\text {st }}$ Century (2009). A Framework for 21st Century Learning. Washington DC: Partnership for the 21st Century.

Petersen, P., McCarthy, S., \& Elmore, R. (1996). Learning from School Restructuring. American Educational Research 
Journal, 33, 119-153. http://dx.doi.org/10.3102/00028312033001119

Plummer, F. (2005). Learning Together through Action Learning. http://www.aare.edu.au/05pap/plu05266.pdf

Republic of Cameroon, Ministry of Basic Education (2012). Organizational Chart.

Republic of Cameroon, Ministry of Basic Education (Department of Projects and Cooperation) (2011). Statistical Year Book.

Rock, T. C., \& Wilson, C. (2005). Improving Teaching through Lesson Study. Teacher Education Quarterly, 32, 77-92.

Rogers, P. (2007). Teacher Professional Learning in Mathematics: An Example of a Change Process. In J. Watson, \& K. Beswick (Eds.), Proceedings of the 30th Annual Conference of the Mathematics Education Research Group of Australasia (Vol. 2, pp. 631-640). Sydney: MERGA.

Shulman, L. S. (1986). Those Who Understand: Knowledge Growth in Teaching. Educational Researcher, 15, 4-14. http://dx.doi.org/10.3102/0013189X015002004

Shulman, L. S. (1987). Knowledge and Teaching: Foundations of the New Reform. Harvard Educational Review, 57, 1-22.

Stigler, J., \& Hiebert, J. (1999). The Teaching Gap. New York: The Free Press.

Supovich, J. A., \& Turner, H. M. (2000). The Effects of Professional Development on Science Teaching Practices and Classroom Culture. Journal of Research in Science Teaching, 37, 963-980. http://dx.doi.org/10.1002/1098-2736(200011)37:9<963::AID-TEA6>3.0.CO;2-0

Tante, A. C. (2010) The Purpose of English Language Teacher Assessment in the English-Speaking Primary School in Cameroon. Encyclopaedia of Language and Education, Language Testing and Assessment, 13, 27-39.

The Research Advisors (2006). http://research-advisors.com/tools/SampleSize.htm.

Upitis, R. (2005). Experiences of Artists and Artist-Teachers Involved in Teacher Professional Development Programs. International Journal of Education and the Arts, 6, 1-11.

Vygotsky, L. S. (1978). Mind in Society: The Development of Higher Psychological Processes. Cambridge, MA: Harvard University Press.

Webb, I. (2007). Key Factors in the Use of ICT in Primary School Classrooms. Ph.D. Thesis, Tasmania: University of Tasmania.

Wenger, E. (1998). Communities of Practice: Learning, Meaning, and Identity. Cambridge, UK and New York: Cambridge University Press. http://dx.doi.org/10.1017/CBO9780511803932

Wenger, E., McDermott, R. A., \& Snyder, W. (2002). Cultivating Communities of Practice: A Guide to Managing Knowledge. Boston, MA: Harvard Business School Press.

Yoon, K. S., Duncan, T., Lee, S. W., Scarloss, B., \& Shapley, K. L. (2007). Reviewing the Evidence on How Teacher Professional Development Affects Student Achievement. (Issues \& Answers Report, REL 2007-No. 033). Washington DC: US Department of Education, Institute of Education Sciences, National Center for Education Evaluation and Regional Assistance, Regional Educational Laboratory Southwest. 
Scientific Research Publishing (SCIRP) is one of the largest Open Access journal publishers. It is currently publishing more than 200 open access, online, peer-reviewed journals covering a wide range of academic disciplines. SCIRP serves the worldwide academic communities and contributes to the progress and application of science with its publication.

Other selected journals from SCIRP are listed as below. Submit your manuscript to us via either submit@scirp.org or Online Submission Portal.
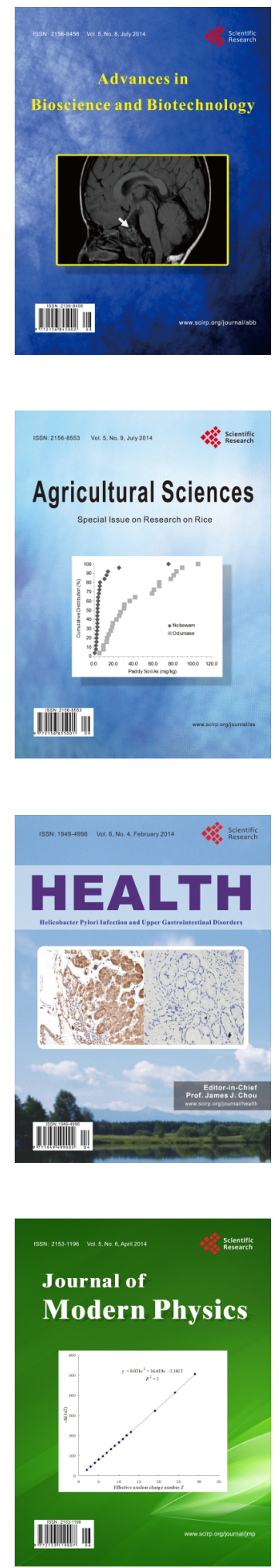
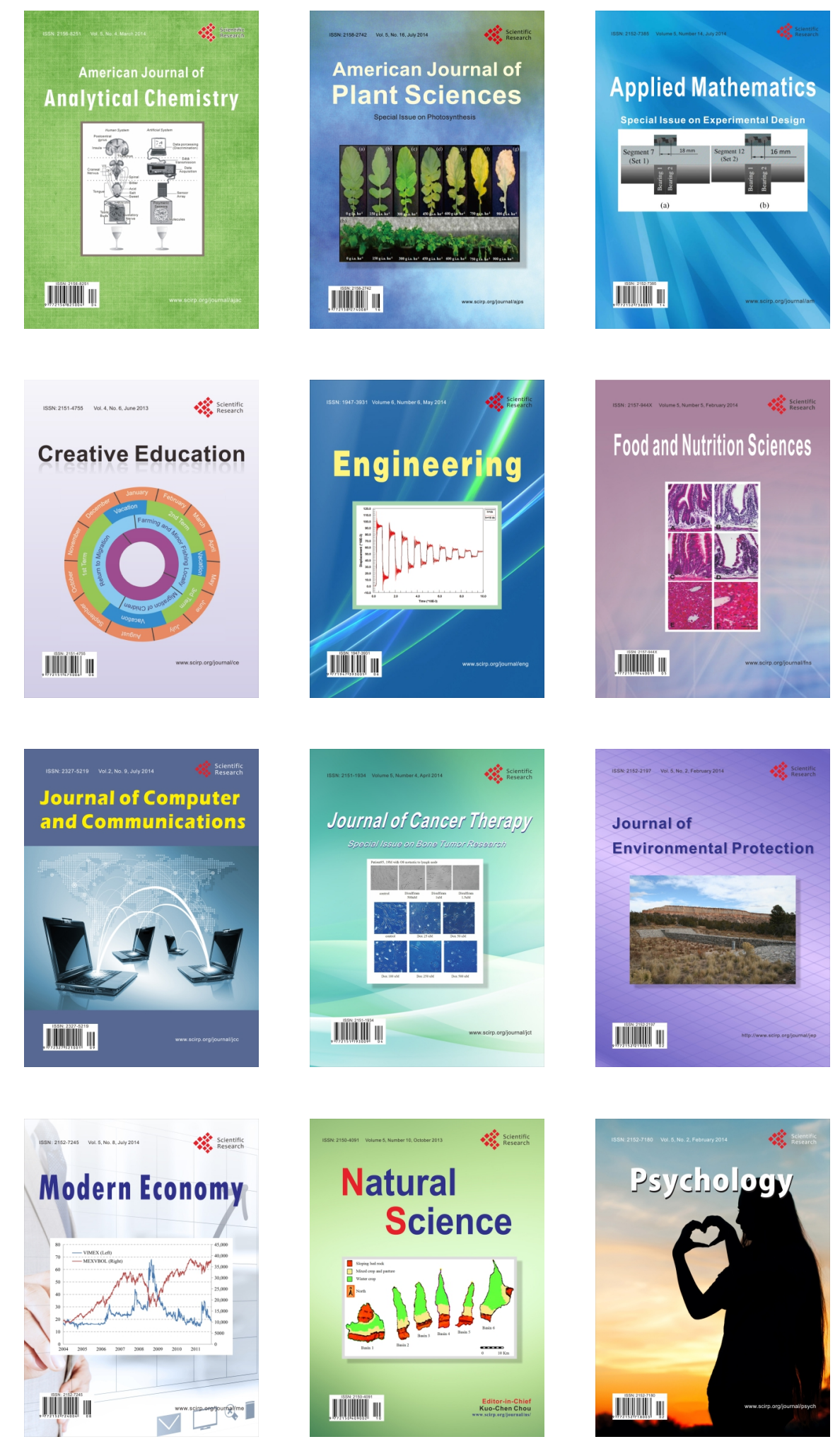